\title{
OPTIMIZATION OF FLOOD PROTECTION BY SEMI-NATURAL MEANS AND RETENTION IN THE CATCHMENT AREA: A CASE STUDY OF LITAVKA RIVER (CZECH REPUBLIC)
}

\author{
Radek ROUB, Tomáš HEJDUK, Pavel NOVÁK
}

\begin{abstract}
Of all natural disasters, floods represent the most serious threat to the territory of the Czech Republic. This is given by the situation of the Czech Republic at the continental as well as the worldwide scale. At present, the design of anti-flood measures is mostly based on technical measures, without considering improvements in the hydromorphological status according to the Framework Directive on Water Management and without considering the natural transformation of flood discharge in the alluvial plains of water courses. This report presents a design for the optimization of anti-flood measures in the pilot catchment of the Litavka River, in which we propose particular measures for the catchment for its entire surface while providing a good hydromorphological status. We also wanted to quantify the proposed measures leading to the increased retention and accumulation capacities of the catchment area.
\end{abstract}

\section{Shrnutí}

\section{Optimalizace protipovodňové ochrany formou přírodě blízkých opatření a retencí v ploše povodí:} př́padová studie Litavky (Česká republika)

Povodňové situace představují na území České republiky největší hrozby př́rodních katastrof. Tato skutečnost je dána polohou České republiky v kontinentálním i celosvětovém měřítku. Návrh protipovodňových opatření $v$ současnosti probíhá předevšim formou technických opatření, bez ohledu na zlepšení hydromorfologického stavu vod dle požadavků Rámcové směrnice o vodách a bez ohledu na prirrozenou transformaci povodñových pri̊toků $v$ nivách vodních toki̊. Př́ispěvek seznamuje $s$ optimalizačním návrhem protipovodňových opatření v rámci pilotního povodí, kde byla navržena konkrétní opatření řešici komplexně povodí v celé jeho ploše a zároveň zajištující dosažení dobrého hydromorfologického stavu vod.

Keywords: retention, GIS, measures, HEC-RAS, floods, HEC-HMS, Litavka River, Czech Republic

\section{Introduction}

Water retention in the landscape can be increased by using appropriately designed anti-erosion and anti-flood measures. In practice, these measures are mostly designed as common measures of complex land adaptations (Podrázský and Remeš, 2006). Appropriately designed and quantified anti-erosion measures have multifunctional effects. Along with limiting soil washout they slow down surface runoff and increase water retention in the landscape (Podrázský and Remeš, 2006).

At present, the design of anti-flood measures (AFM) is mostly based on technical measures, without considering improvements of the hydromorphological status according to the Framework Directive on Water Management and without considering the natural transformation of flood discharge in the alluvial plains of water courses. Careless interventions into alluvial plains may cause decreased retention in these inundation territories. Vopálka (2003) reported that without the existence of an elaborated information system and a complex concept of the landscape, no serious solution of flood protection can be found.

The occurrence of a number of disastrous floods in Europe in the last 15 years (affecting Bulgaria and Romania) has led to a significant focus in water management policies on improving anti-flood protection and the implementation of anti-flood 
measures in order to decrease the flood damage (Munzar et al., 2008). Following these disastrous events, the European Parliament and Council adopted a Directive (2007/60/ES of October 23, 2007) on the evaluation and management of flood risks.

Even in the conditions of the Czech Republic (CR), the issue of floods represents an increasingly pressing problem with regard to the experience from recent years - 1997 floods in Moravia, 2002 and 2006 floods in Bohemia, 2009 rainstorm floods in the region of Nový Jičín and Jesenice, and 2010 rainstorm floods in North Bohemia. For these reasons, great attention is paid to flood prevention measures, which should anticipate these events, eliminate their potential and manage them organizationally. According to their characteristics we classify the anti-flood measures into three different groups - preventive measures, measures in danger of floods or during the floods, and measures after the floods (Act No. 254/2001 of the Collection of Czech Laws).

One of the often cited reasons for the occurrence of runoff extremes in relation to the increased frequency of extreme hydrologic situations that have affected the Czech Republic in several recent years is the decreased retention and accumulation function of the landscape. The reduced retention capacity of a territory is manifested as a consequence of the growing compactness of soilandlong-lastingadverse exploitation of the territory, which mostly results from the growing pressure for building in the inundation areas with otherwise standard retardation and accumulation of runoff (Bičík et al., 2008; Trimble, 2003). Analysis of changes in land use development is of interest to a number of authors (Skaloš et al., 2011; Shalaby and Tateishi, 2007). Inundations, retardation and accumulation elements in the landscape together form the 'retention potential' of the landscape, which influences the capacity of the territory to transform the causative rainfall into runoff, determines its course and culmination together with further transport of substances released mainly by e.g. erosive processes (Magunda et al., 1997). Retention in a catchment is mostly determined by different involvement and function of retention and accumulation elements during the occurrence of causative rainfall of various types (rainstorm, regional rainfall), depending on the size of the affected area and the current physical or technical status of the retention elements in the course of rainfall occurrence (Mahe et al., 2005).

From the hydrologic point of view, 'small water circulation' should be promoted in the landscape. This circulation means water evaporation from the surface and its deposition in the form of rainfall occurring within one territory of the landscape. The significance of this small water circulation mainly lies in water retention, contributing to the microclimate balance (Petříček and Cudlín, 2003).

Petříček and Cudlín (2003) also reported that the retention capacity of a landscape itself is given by the landscape's capability of retaining water and in this way retarding rainfall runoff from the territory. This term should mean temporary retention of water in the vegetation, objects located in the catchment, water retention in the layer of soil covering the surface, in the soil itself, micro depressions, dry retention reservoirs, and in the 'runoff-less' phase of the rainfallrunoff process. Additionally, this landscape function contributes to a more balanced hydrologic cycle (lower occurrence of extreme conditions - floods, droughts) and to lower washout of nutrients.

An important role in the retention capacity of a landscape is played by landscape elements such as forest ecosystems, natural water courses and alluvial plains, meadows, soaking belts, etc. Elimination of these elements from the landscape results in fast water runoff, erosion, the loading of water courses with washed out soil containing high nutrient content, but also in a significant drop in the supply of underground water. An effective form of retaining high water quantities in the landscape is also represented by wetland biotopes, spring areas, peat bogs, pools, pond littorals, river alluvial plains, waterlogged pine woods, etc. (Mauchamp et al., 2002). By their action they contribute to suppression of the flow extremes and to transformation of the flood wave. Wetlands protect the landscape against floods because they create spaces for retaining and accumulating water at the time of flood discharge, when they act as water reservoirs. Studies have reported that 0.4 ha of wetland can retain more than $6,000 \mathrm{~m}^{3}$ of water (Klementová and Juráková, 2003).

Similarly, grasslands limit the surface runoff by their retention capacity. Besides, non-compacted, humous and structured soils of grasslands possess a high infiltration capacity. This effect plays a role mainly in sloped lands, where permanent grass covers increase the soil retention capacity, particularly during rainstorms and long-lasting rains (Hrabě and Buchgraber, 2004; Hornbeck et al., 1997).

A positive role is also played by forests, which reduce the volume of out-flowing flood water. The transformation effect of woodlands is most visible namely at the beginning of flood events. Runoff formation mainly depends on the structure, thickness, form, degree of looseness and integrity of litter in 
forest ecosystems. Křovák et al. (2004) described their results from hydrogeologic observation in the Šmava National Park, showing that forest soil is capable of retaining 30 to $50 \mathrm{~mm}$ of precipitation. With higher daily values or repeated rainfall in short time intervals, water runoff occurs regardless of the catchment forestation or its species structure. Similar results were obtained by other authors, for example Chlebek and Jařabáč (1988), Tesař et al. (2003), Adamec et al. (2006), Adamec and Unucka (2007), and Jeníček (2009). The retention capacity of forest soils plays significant geomorphologic, hydrologic and environmental roles. The amount of water retained in forest soils represents a key factor in forest fire forecasts, forming a significant water supply for plants, and evaporation from the forest soil contributes to the transport of water and energy in the landscape (Kosugi et al., 2001).

In the conditions of the Czech Republic, the soils are capable of receiving and retainomg much higher amounts of water than the volume in all Czech water reservoirs. Soil is an important filtration, retention and transport environment with values of 50-320 $1 . \mathrm{m}^{-3}$ (Prospective and Situation Report of the Ministry of Agriculture on the Soil from 2006). Water retention capacity reflects the capability of soil to absorb and retain rainfall water before leaving the landscape (Hall et al., 1977).
Retention of soil is positively correlated with the organic mass content in the soil and negatively correlated with the soil volumetric mass, content of particles exceeding $100 \mu \mathrm{m}$ and with the decreasing thickness of the upper soil layer (Hall et al., 1977).

Based on the above-mentioned facts, we described the possibility of employing an alternative approach to technical anti-flood measures in the form of seminatural measures and retention in the catchment area. To date, quantification of the retention effect of technical anti-flood measures (AFM) has already been well-elaborated, as reported by Weyskrabová et al. (2010). The aim of our work was therefore to quantify the retention potential of the designed measures in the landscape enabling for example augmentation of water infiltration in the soil, reduction of surface runoff, or definition of the area for directed surface spill (controlled flood areas).

\section{Study area}

As a pilot area we selected the catchment of the Litavka River (1-11-04), which represents a large area SouthWest of Prague. The Litavka R. drains water from a large part of the Brdy Uplands, springing between the peaks of Tok (865 m a.s.l.) and Praha (862 m a.s.l.) at $765.66 \mathrm{~m}$ of altitude. Litavka is a right-hand affluent of the Berounka River, with its mouth near the town of

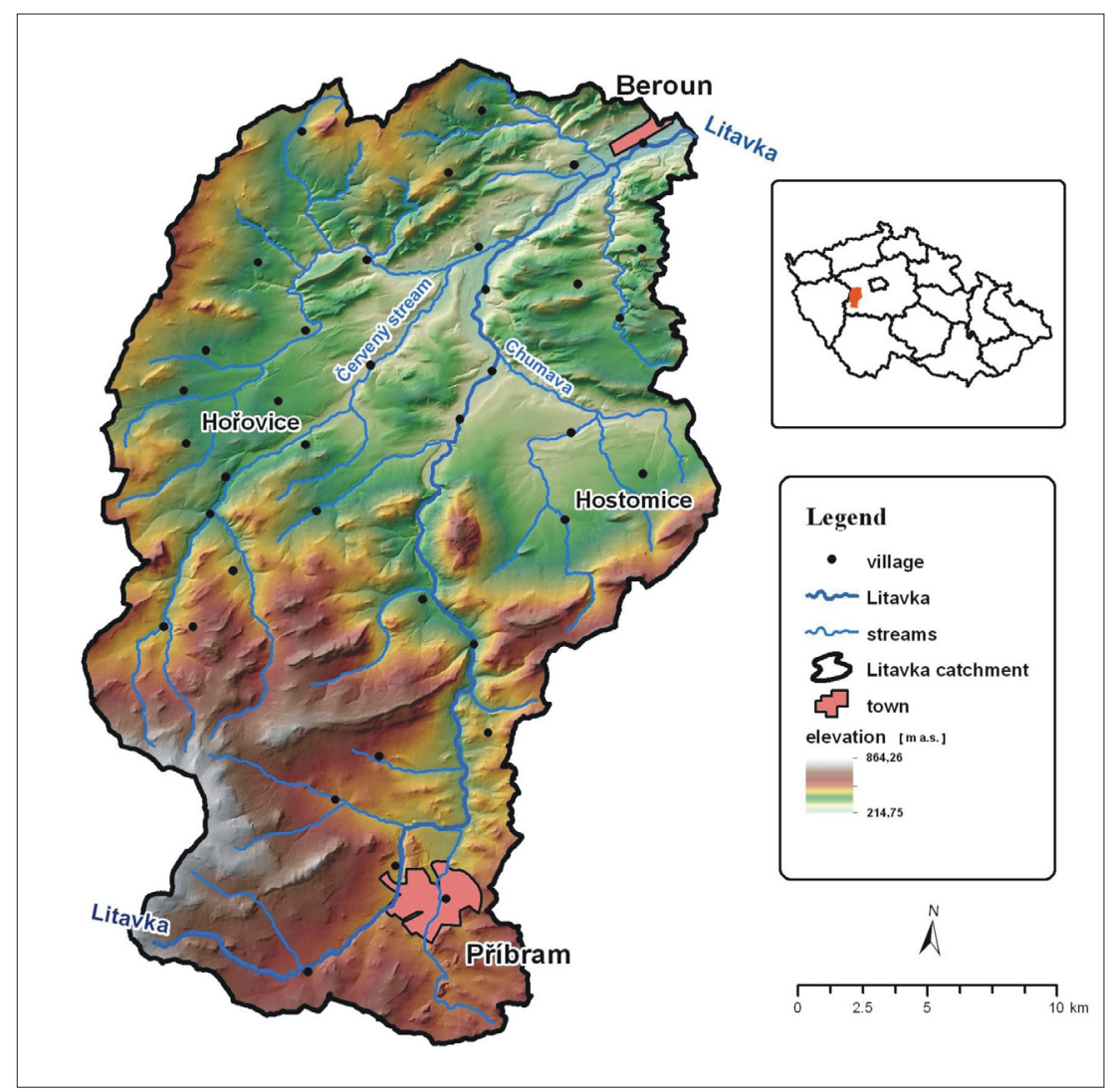

Fig. 1: Study area 
Beroun at its $33.96 \mathrm{~km}$. The catchment, which is mostly formed by two partial catchments of the main affluents Chumava and Červený potok, covers the surface of $628.75 \mathrm{~km}^{2}$. The catchment contains 538 water surfaces with a total area of 225.11 ha. The largest of them are water reservoirs Pilská (20.54 ha), Láz (15.01 ha), Obecnice and Záskalská. The main factor determining the local climate is the altitude. With the increasing altitude the temperatures drop and precipitation increases. According to Quitt (1971), the catchment belongs to the climatic regions $\mathrm{CH} 7$ (spring part), MT3, MT5 (Březové hory Mts.), MT7, MT11 (Hořovická brázda Furrow), T2 (Zdická brázda Furrow). The area of interest is delineated in Fig. 1.

\section{Material}

\subsection{Data for schematization of the stream channel and inundation of the Litavka water course}

Among the most relevant data for hydrodynamic models are the entry data for schematization of the stream channel and water course inundation (Giannoni et al., 2003; Havlík et al., 2004; Fowler et al., 2005; Drbal et al., 2009). Data for schematization of the water course also determine the choice of the hydrodynamic model itself (Merwade et al., 2006; Merwade et al., 2008), while with regard to the requirements of altigraphic description of the water course, there are less demanding are one-dimensional (1D) models required for calculating only lateral stream channel profiles and adjacent inundations. In the case of twodimensional (2D) models, the calculations already require a detailed digital model of the terrain precisely describing the morphology of the studied area.

To create the hydraulic model we utilized data from aerial laser scanning (ALS) in combination with geodetic surveying of the lateral stream channel profiles and objects located at the water course.

The $2 \mathrm{~m}$ DMT resolution was used to obtain relevant results from the hydrodynamic model.

\subsubsection{Data from aerial laser scanning}

Aerial laser scanning represents a relatively recent technology enabling the collection of large amounts of data within a relatively short time interval (Dolansky, 2004). The obtained altigraphy data may be applied to a number of practical disciplines.

Brázdil (2009) defined the principle of ALS as a method based on the reflection of laser rays interpreting the image of measured objects as a cloud of points. Brázdil (2009) also described the ALS method as one of the most effective methods for obtaining spatial data characterized by a relatively high degree of automation of processing during the creation of a digital model of the terrain (DMT) or a digital model of the surface.

For assessments in our alternative approach to AFM we employed data from the ongoing altigraphy mapping of the Czech Republic using the ALS method, which is conducted under the auspices of the Czech Office for Mapping, Surveying and Cadastre with the participation of the Ministry of Agriculture and Ministry of Defence (MD). The advantage of this method lies in the fast measurements, achieved precision, and amounts of the measured data and information. The new altigraphic record of the Czech Republic has achieved point density higher than 1 point $/ \mathrm{m}^{2}$ and total mean altitude error of $0.18 \mathrm{~m}$ in the open terrain and $0.30 \mathrm{~m}$ in the forested terrain (Brázdil, 2009).

The ALS data provide a high-quality background for applications in hydrodynamic models, and the usability of these data for mathematical modelling is presented in the publications by Novák et al. (2011), Roub et al. (2012), Uhlířová and Zbořil (2009).

\subsubsection{Data from geodetic location}

For a more detailed DMT prepared from the ALS data, i.e. for completing its relevant image in the area of the stream channel itself, we employed geodetically surveyed lateral profiles of the water course stream channels in the studied area (the ALS ray is absorbed by the water surface during the data acquisition). Geodetically surveyed lateral profiles of the water course stream channels were provided by the company Povodí Vltavy, s.p. - affiliation in Pilsen. The distance interval of the surveyed stream channel profiles was in the range from $50 \mathrm{~m}$ to $250 \mathrm{~m}$. A shorter interval of $50 \mathrm{~m}$ was applied in residential areas of villages situated at the water course, while a longer interval of interprofile distances was used outside these residential areas, providing an adequate background for further operations, as also reported by Novák et al. (2011).

\subsection{Programming means for assessing AFM optimization}

The choice of the models and software for optimization of the designed flood-control measures was based on high compatibility with the ESRI products. For these reasons, we selected the products of HEC (Hydrologic Engineering Center) developed by the US Army.

The geographic information systems (GIS) were defined by Rapant (2002) as computer systems for geographic data processing. Voženílek (2000) defined GIS as an analytical tool serving to link the geographic information (data on the situation, localization of the 
object) with the descriptive information (data on the object characteristics) by computer programmes. A more detailed explanation of the GIS notion defined at the level of relevant application was given by Rapant (2005), describing GIS as a functional unit formed through the integration of technical and programming means, geodata, working processes, user operation, and organizational context.

\section{HEC-HMS}

The HEC-HMS model (Hydrologic Engineering Center - Hydrologic Modelling System) represents a successor to the HEC-1 model (already developed since the 1960s). It is a representative of lump semidistributed models, but great attention is currently paid to the development of components with distributed parameters. At present, this software is the most extensively used rainfall-runoff model in the USA and among freeware programmes, probably in the world as well. The model offers an advanced user interface and high flexibility in parametric representation of the rainfall-runoff model.

Its native complements are HEC-GeoHMS, an extension for ArcGIS 10 (required Spatial Analyst) serving for pre-processing and schematization of the catchment from the digital terrain model, and software managing the time rows of meteorological data and results of HEC-DSSVue simulations.

To prepare the geometric data and final visualization we also used the HEC-GeoHMS, representing a set of tools and aids for processing the hydrologic characteristics of the catchment in ArcGIS using the graphic user interface (GUI). The HEC-GeoHMS extension is associated with another extended upgrade, ArcHydro Tools (Maidment, 2002), and both extensions enable acquisition of data on the catchment border, runoff directions, water accumulation, etc., all this based on the initial DMT.

\section{HEC-RAS}

The hydraulic computing system HEC-RAS - River Analysis System is intended for complex modelling of surface water courses. The HEC-RAS programme enables one-dimensional computing of both steadystate and irregular flow, sediment load transport (moving bed) or modelling of temperature changes of streaming water. The computing scheme for steadystate flow is based on the calculation of irregular water flow in stream channels using the sectional methods. The programme enables distribution of the profile into the stream channel itself ('effective' discharge area) and the left and right inundations.
Establishment of the level course in the HEC-RAS software is based on the one-dimensional solution of Bernoulli's equation (energy equation). Energetic loss is determined in the form of friction loss (Manning's equation), where local losses are expressed by coefficients (contraction/expansion coefficients). Hydraulically complicated locations such as spills, confluences, bifurcations, bridges or culverts are solved by the adapted motion equation.

To prepare geometric data and final visualization, we also used the HEC-GeoRAS extension, which represents a set of tools and aids for processing geospatial data in ArcGIS using a graphic user interface (Anderson, 2000; Colby et al., 2000; Andrysiak and Maidment, 2000). The interface enables preparation of geometric data in the form of schematization of the computing track followed by export into the HEC-RAS environment. The HECRAS programme was used to perform the required simulations and the results were imported back to the ArcGIS environment, where they were further visualized and underwent additional analyses (Novák et al., 2011).

\section{ArcGIS}

To assess the design of AFM for the Litavka R. catchment we used integrated, scaleable and open GIS in the form of ArcGIS made by ESRI, which offers robust tools for editing, analysis and management of data, making it the most complex GIS software on the market worldwide (Čejp and Duchan, 2008).

Particularly for the preparation of entry data and for the final visualization of the obtained results we used two specific upgrades, Spatial Analyst Tools and 3D Analyst. Spatial Analyst Tools offers a large array of tools for spatial modelling and analysis, which enable creating images, enquiring and analysing raster data. 3D Analyst provides users with effective visualization and analysis of representing data.

In the context of utilization of hydrologic models this software offers a number of functions (namely of the group Spatial Analyst Tools, 3D Analyst Tools) and particularly further extensions (HEC-GeoHMS, HECGeoRAS).

\section{Methods}

Taking into account novel data in the field of flood protection, semi-natural flood-control measures and retention in the catchment area are understood by the professional community not only as a merely complementary technical anti-flood measures, but 
also as one of the possible alternatives. This is due to their additional potential to effectively transform the surface runoff to groundwater runoff, replenishing the supply of underground water, creating important landscape-forming elements, eliminating erosion, and positively influencing water quality.

During the optimization of AFM in the pilot catchment of Litavka R. we proposed specific measures for complex management of the catchment in its entire surface and at the same time for ensuring a good hydromorphologic status of water.

The proposed measures in the catchment area were based on the changes in the character of vegetation and soil cover in the catchment. The influence of the vegetation on the rainfall-runoff process, and thus on the quantity of water for potential runoff from the catchment, was described by Likens and Bormann (1974); Pobědinskij and Krečmer (1984), Kantor et al. (2003), Unucka (2008), and Unucka and Adamec (2008).

Reactions of the catchment to the changes in vegetation cover were prepared in two scenario variants. Modelling of changes in runoff regime in the first variant assumed $50 \%$ grassing of land with theprotection of the agricultural soil fund (ASF). In the second variant, the mathematical representation of the rainfall-runoff process was carried out on the basis of assuming as much as 100\% land grassing with ASF protection in the catchment.

Because of the low demand for entry data the calculation of runoff volume was done using the SCS CN Soil Conservation Service Curve Number method (Mishra and Singh, 2003) employing CN curves to calculate the runoff loss (Janeček, 1992; Holý, 1994; Boonstra and Ritzema, 1994; Ponce and Hawkins, 1996, Feldman, 2000; Trizna, 2002; Trizna and Kyzek, 2002). Alternatively, the method of exponential decrease, constant infiltration, and the Green-Ampt method may also be used, which will be implemented in our further research.

The effective precipitation is determined by the SCS CN method employing the function of precipitation sum, soil properties, vegetation cover and previous saturation, and is calculated by using the following equation (1):

$$
Q=\frac{\left(P-I_{a}\right)^{2}}{\left(P-I_{a}+S\right)}
$$

where $Q$ is surface (Horton) runoff in time $t[\mathrm{~mm}]$, $P$ is cumulative rainfall in time $t[\mathrm{~mm}], \mathrm{I}_{\mathrm{a}}$ is Initial Abstraction [mm].
$S$ is potential maximum retention defined by equation (2):

$$
\mathrm{S}=25.4 \times(1000 / \mathrm{CN}-10)
$$

where $C N$ is the $\mathrm{CN}$ curve number [-].

Potential maximum retention is calculated from the CN curve, determined by Janeček (2002) in relation to the hydrologic group of soil (Novák, 2003) and landscape cover.

Regarding the characteristics of the Litavka River catchment and its saturation, the $C N$ values between 65-80 were used. To determine the value of direct runoff one can choose from various modifications of unit hydrogram (Clark, Snyder, SCS). We selected the Clark's method of unit hydrogram in our assessment.

To calculate the underground runoff, as stated by Jeníček (2008) the user can choose from various approaches. They include the model of linear reservoir $\left(\mathrm{O}^{\prime}\right.$ Connor, 1976) and exponential decrease (Chow et al, 1988). To create this model we used the method of exponential decrease defining the amount of underground runoff in the given period of time based on the initial underground runoff.

Monitoring the effect of hydromorphology of the water course itself was based on significant contrast intensity of anthropogenic interventions into the Litavka $R$. catchment. The spring area and the upper profile of Litavka R. display a relatively natural character in contrast to intensive industry, extensive agriculture and higher proportion of urbanization in the middle and lower parts of the water course. Langhammer (2007) described adaptations to the river network and alluvial plain as a significant factor influencing the runoff process during the floods. In general, adaptations to the river network and alluvial plain have significant impact on the course of flood wave, transformation effect of the alluvial plain as well as effectiveness of utilization of the retention potential of the territory (Žikulinas, 2008).

Taufmannová and Langhammer (2007) described the stream channel of Litavka R. in almost all its length as directionally balanced in the requirements of the residential areas of settlements and employment of agricultural streamside land. Of the total length of the Litavka water course, $88 \%$ have been adapted to some extent. A purely natural stream channel can only be found above the Láz water reservoir and between river $\mathrm{km}$ 20.5-18.8. A number of adapted sections have spontaneously revitalized and their character has become semi-natural. The occurrence of such seminatural sections at the Litavka River has been assessed 
as ca $45 \%$. The most significant human interventions were recorded in the upper Litavka $R$. between Bohutín-Příbram-Lhota, near Čenkov and Jince, and from Lochovice the river is led through a trapezoidal stream channel to its mouth in Beroun (Havlová, 2001). Kaiml (2000) classified most adaptations into the group of fortifications dating from the 1970s.

With respect to the transformation effect of flood events, the most significant role is played by the geometry of the lateral and longitudinal profiles. For these reasons we adapted the initial DMT, in which we changed the lateral profile in locations of the water course with high stream channel capacity, and the longitudinal profile was modified in order to promote forking and surface spill into the alluvial plain.

Outside the residential area of settlements, the AFM were therefore designed to decrease the capacity of the stream channel and to augment the frequency of surface spill into alluvial plains, contributing to the natural transformation of flood discharge. In the territories inside the residential area of settlements, DMT was modified with the aim to increase the capacity of the stream channel and accelerate the runoff; we also proposed a composed profile with mobile cunette, including the possibility of damming the built-up areas or installing movable dams. While planning the AFM we also found locations with favourable profiles for the transformation of the flood wave in dry retention reservoirs or polders, which however were not included into this stage of assessment.

The setup of the hydrodynamic models for comparative analyses of the present state after AFM design was made using a 1D hydrodynamic model in HEC-RAS software.

\section{Results and Discussion}

The goal of our report was to set up rainfall-runoff models for modelling the retention measures in the area of the catchment and for the design of a new lateral profile of the Litavka River, i.e. adaptation of its present layout. The design of AFM was followed by the setup of hydrodynamic models for the assessment of the proposed measures. We compared the present state with conditions reflecting the retention measures in the area of the catchment, including hydromorphologic measures at the water course itself. The comparison of particular scenarios was focused on verifying the contribution of the suggested seminatural flood-control measures, including measures in the catchment area aimed at transforming flood waves and eliminating the extent of flood threats.

A significant step to calibration of the real event model was represented by the setup of the initial layer of landscape cover, which was delineated in a combination of data sources from CORINE (COoRdination of INformation on the Environment), see Fig. 2, and LPIS (Land Parcels Information System), see Fig. 3. For higher resolution we also considered including data from digital cadastral maps (DCM) or digitized cadastral maps (CMD) into the final image; however, with regard to the stage of their processing $(1 / 3$ of the catchment) we abandoned this idea.

The simulation itself of the effect of landscape cover was based on a selected event related to the rainfallrunoff episode of August 2-26, 2002. The sum of precipitation for the period of August 6-12, 2002 exceeded the values of $150 \mathrm{~mm}$ in all precipitation gauge stations in the catchment. The culmination flow in the closing profile (Beroun profile) reached the value of $244 \mathrm{~m}^{3} \cdot \mathrm{s}^{-1}$, corresponding to a 10-year flood event $\left(\mathrm{Q} 50-263 \mathrm{~m}^{3} \cdot \mathrm{s}^{-1}\right)$. The precipitation sums reached at individual gauge stations are given in Table 1.

The modelled flood event (Fig. 4) discussed here represents a characteristic reaction of the Litavka $R$. catchment to a precipitation event. Typically there is a very fast response of the catchment, which in this case reacted namely to the precipitation in the period of August 11-12, 2002, reflected in the hydrogram in the form of two separate culmination flows with values of $244 \mathrm{~m}^{3} \cdot \mathrm{s}^{-1}$ and $214 \mathrm{~m}^{3} \cdot \mathrm{s}^{-1}$, respectively.

\begin{tabular}{|c|c|c|c|c|}
\hline \multirow{2}{*}{ Date } & \multicolumn{4}{|c|}{ Total precipitation amount [mm] } \\
\cline { 2 - 5 } & Láz & Obecnice & Pilská & Záskalská \\
\hline 6.8 .2002 & 18.3 & 17.1 & 18.1 & - \\
\hline 7.8 .2002 & 21.1 & 23.5 & 4.1 & 0.4 \\
\hline 8.8 .2002 & 2.4 & 39.0 & 4.1 & - \\
\hline 9.8 .2002 & - & - & - & 3.1 \\
\hline 10.8 .2002 & - & - & 31 & 64.0 \\
\hline 11.8 .2002 & 35.0 & 40.0 & 52.0 & 58.0 \\
\hline 12.8 .2002 & 106.3 & 76.9 & & - \\
\hline
\end{tabular}

Tab. 1: Precipitation at stations 


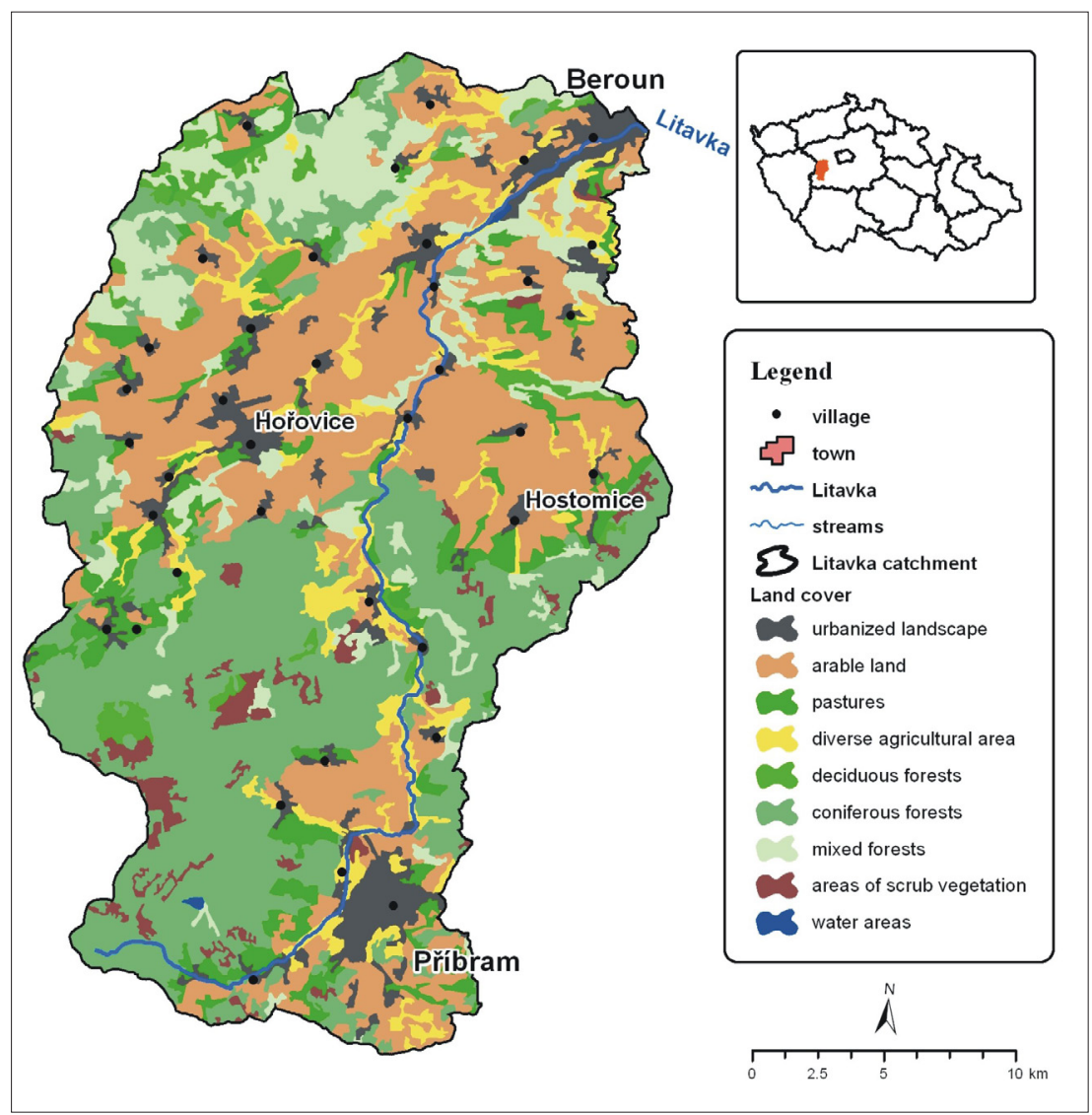

Fig. 2: Land cover (CORINE)

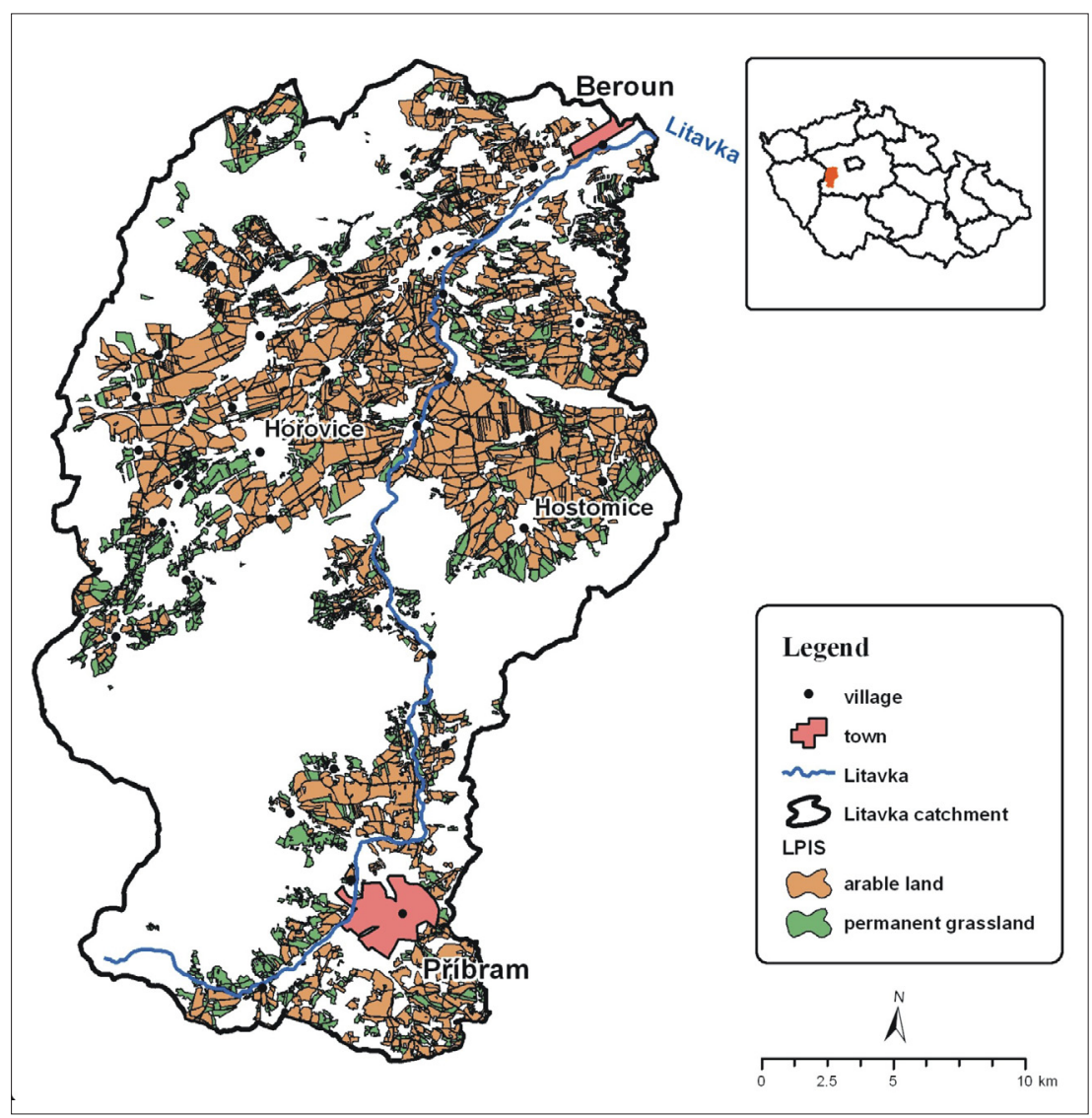

Fig. 3: Land cover (LPIS) 


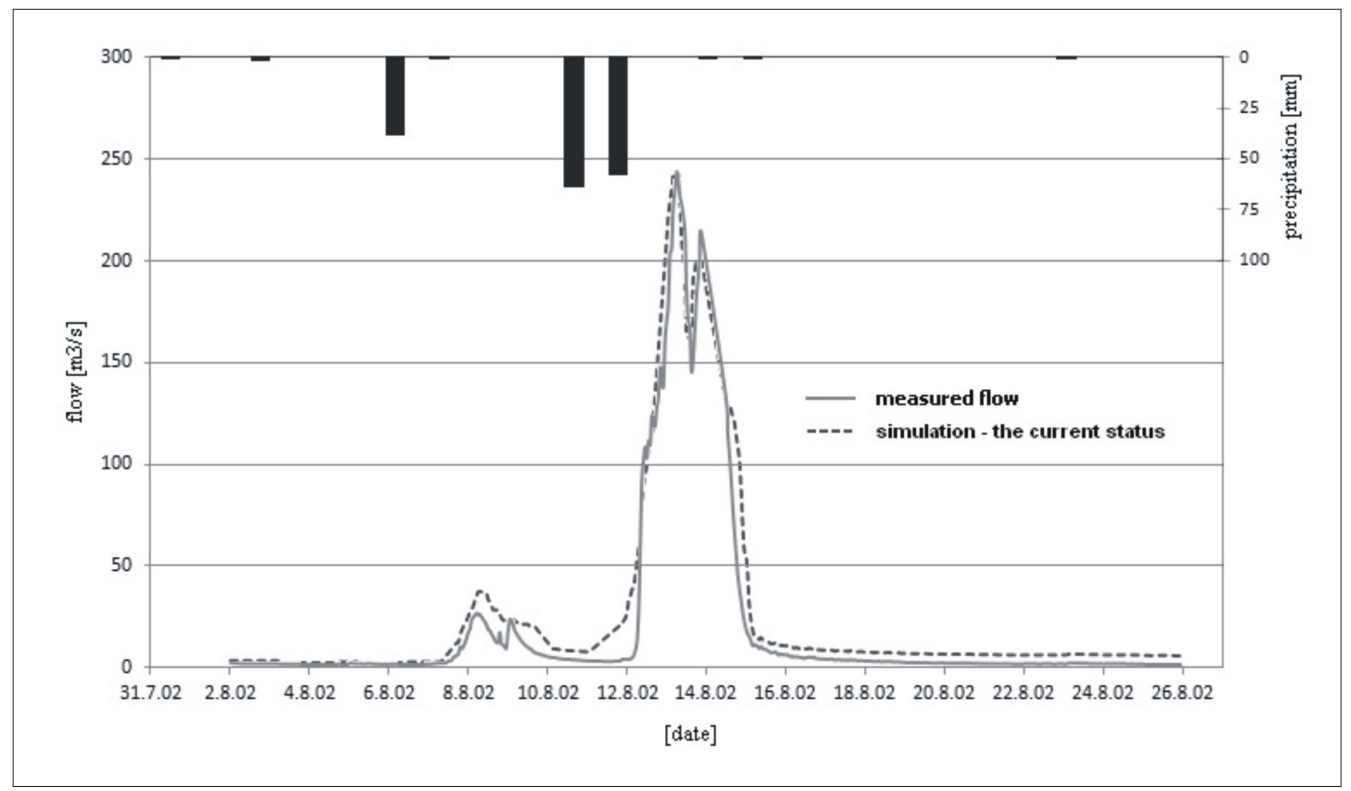

Fig. 4: Flood event (simulated flood event) in August 2002

For the event simulation itself (August 2-26, 2002) in the programme HEC-HMS we succeeded in recording both culmination values (Fig. 4), and mainly in the case of the first one we achieved a very satisfactory correlation. The recording of the second culmination was not so successful, which was already caused by a partial drop between the culminations.

The results obtained by simulation of the landscape cover adaptations for the scenario of total grassing of ALF (Fig. 5) are demonstrated by the transformation of the flood event to the culmination flow of $184 \mathrm{~m}^{3} \cdot \mathrm{s}^{-1}$, representing a $15 \%$ drop compared to real conditions. The scenario based on $50 \%$ grassing was not further analysed because we did not obtain evidence for an effect of the landscape cover on the monitored flood event. In case of $100 \%$ ALF grassing, we can also see a shift of culmination itself, which in this simulated scenario reached only one culmination value. The hydrograms of the measured flows, including simulation of the current state of landscape cover and simulation with $100 \%$ ALF grassing, can be seen in Fig. 6 .

To prepare the hydrodynamic model for assessment of the semi-natural measures we used two DMTs. For the first variant we used the DMT reflecting the real state of the territory. For the second variant, the initial DMT was adapted according to the given methodology. To achieve relevant results we used ALS data for DMT construction and the preparation of computation

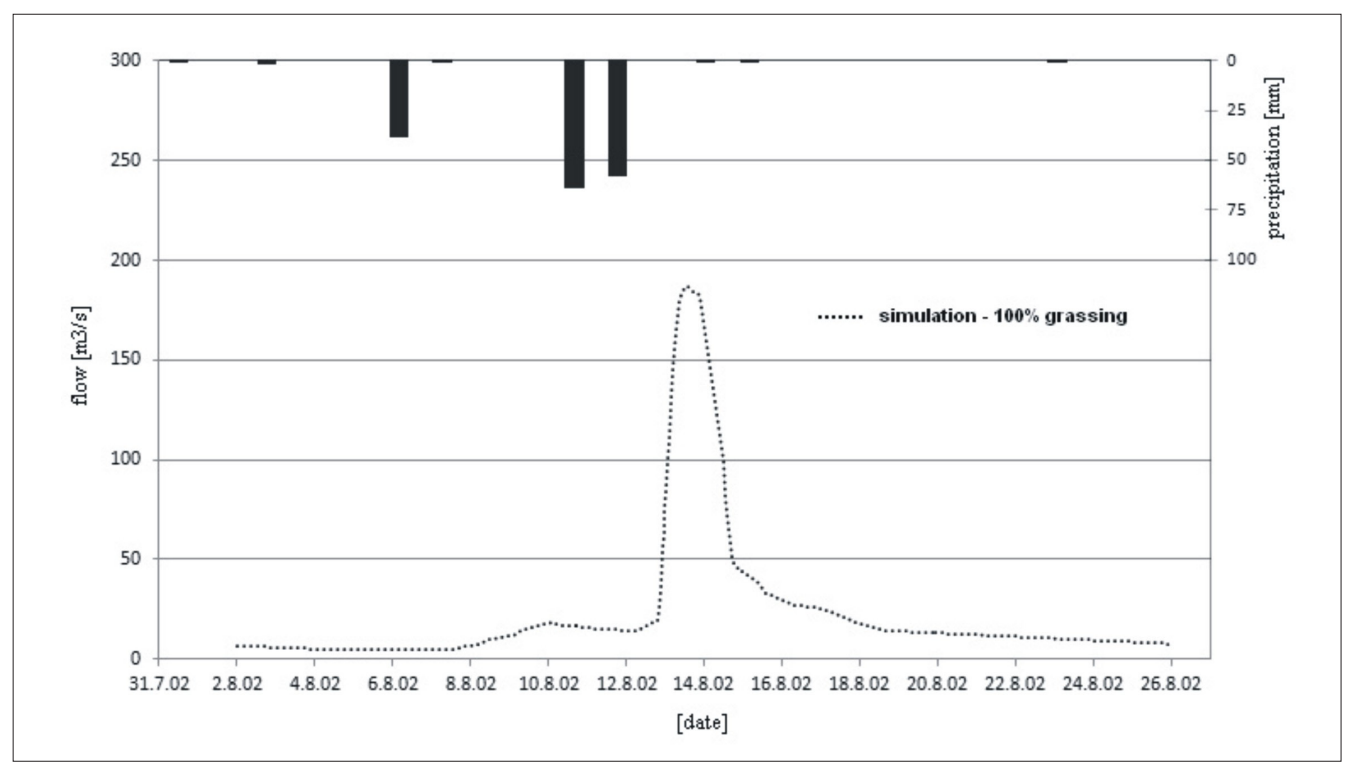

Fig. 5: Influence of grassing basin 


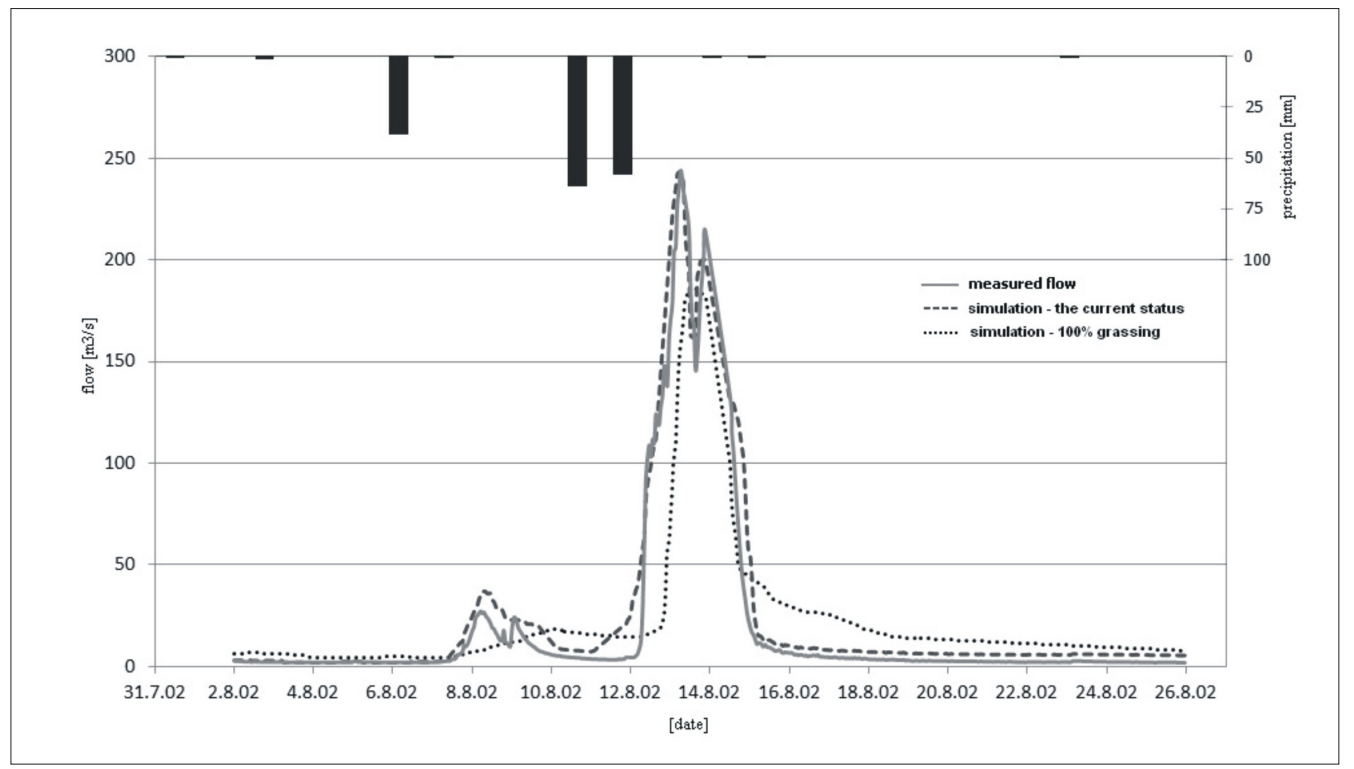

Fig. 6: All scenarios for flood events in August 2002

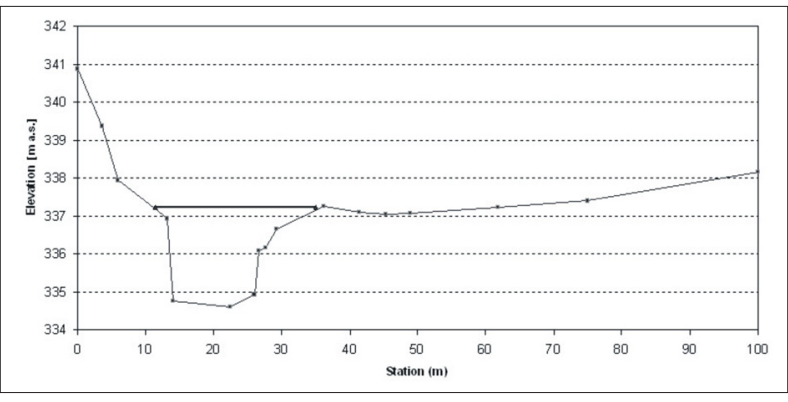

Fig. 7: Crosssection variations a

geometry of water courses, which were elaborated in more detail by subsequent surveying and existing data stores (geodetically surveyed lateral profiles). This approach is shown in Fig. 7 and Fig. 8.

The main goal of flood-control measures is to provide for the discharge capacity of the river bed and adjacent river inundation in order to divert the excess volume of the flood water with the least problems possible. Principally this means the removal of deposits from the river bed, an appropriate structure of vegetation and agricultural management in the inundation, minimal building in the active river inundation and other measures. The second goal is to decrease the extent of flood wave culmination and deceleration of its progress. This can be achieved by building dams and, to a lesser extent, polders by using ponds with flood pre-manipulation and namely by enabling natural lateral surface spills of the flood wave into the inundation.

While designing dams we must take into account that the main problem in Bohemia is lack of water. This means that the dams must retain part of the flood volume for dry periods, which in this region

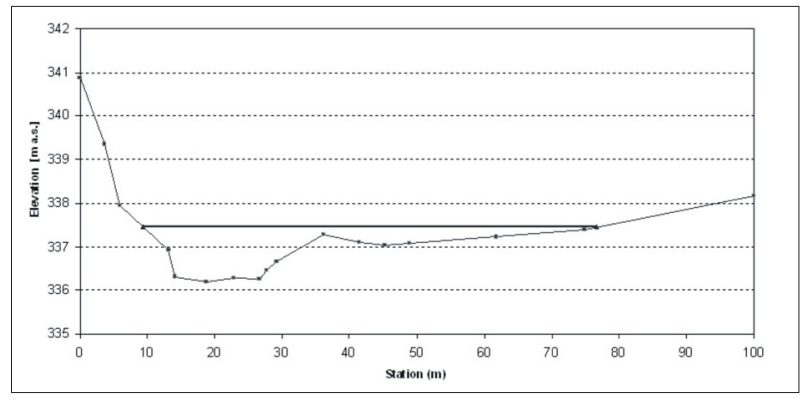

Fig. 8: Crosssection variations b

occur in multiple-year cycles. Of high significance among flood-control measures is prolongation of the prognosis time for the precipitation volume and flood discharge using the most recent mathematical programmes and subsequent mathematical modelling of surface spills, depth and speed of water in the courses during the particular flood. The results of the mathematical modelling recorded in the orthophotocharts and digitized cadastral maps represent an excellent background for early anti-flood operations in the inundation area before the onset of flood culminations.

For some objects, unfavourably built in the past in the submersion area of the river, in justified and economically acceptable cases, protection can be provided by building protective dams and compacting the subsoil, or optionally by draining the underground water. The construction of flood dams, however, must be performed with caution, when possible in an inactive flow zone, in the least possible volume of the protected area, and after detailed investigation of the effect on the river levels upstream and downstream from this construction and of the effect on underground water outside the flood construction. 
The flood-control dams provide protection against floods only to the extent of the designed flow capacity. When this extent is exceeded, the protected area is flooded. These only locally effective flood-control constructions are very costly, mostly because of the need to compact the subsoil. The solution is often complicated by communications, sewage, distribution systems, and local brooks. Although the flood-control dams are often combined with short-term-use movable walls, the intervention into the landscape and land appearance is significant.

To confirm the proposed hypotheses about the effect of water course tracing on the transformation of flood discharge and on the effect of the landscape cover on the retention in the catchment area we simulated three scenarios in the environment of the hydrodynamic model. The first scenario was prepared based on the real state of the catchment and served as a reference. The second scenario employed identical hydrologic data as in the first case but used an adjusted DMT. The third scenario was based on the adjusted DMT, but also on the results obtained during rainfall-runoff simulations with changed landscape cover. The last scenario thus evaluated the entire system of the proposed measures, in the catchment area as well as in the alluvial plain of the water course.

The results obtained using the hydrodynamic model clearly point to the justification of the assumed hypotheses (Fig. 9). Although the effect of grassing during the simulation of the precipitation event was not so marked as shown by other authors, e.g. Unucka and Adamec (2008), (who studied the effect of landscape cover in the Olše River catchment and achieved as high as 56\% transformation of the precipitation event with $100 \%$ catchment forestation, the transforming potential of grassing observed in this project was positive. The lower transforming capacity of grassing may be caused primarily by the morphology of the Litavka R. catchment (Fig. 10), characterized by the documented fast reaction to the precipitation event, and this may lead to a less noticeable retention, i.e. infiltration potential.

The assessment of AFM on the water course itself led to the conclusion that beside the transforming potential of inundation there is a significant shift of the culmination, which provides the time needed for possible evacuations of threatened persons and protective work during the crisis management of the crisis.

\section{Conclusion}

In the Czech Republic, there is still a tendency to manage the hydrological problems using technical measures, which offer fast but only one-sided solutions. Preference is given to the measures of the type of protective reservoirs, dams, or increased river bed capacities, which result in further water management problems lower downstream however, and cause serious ecological problems.

This report contributed to the validation of the transforming effect of semi-natural flood-control measures and retention measures in the catchment area. In addition, we also found a positive contribution of the ALS data to the creation of hydrodynamic models in variant conditions of DMT formation.

In view of the disastrous floods observed in the recent decade, the issue discussed in this report is very pressing, also with regard to the Floods Directive adopted by the European Parliament and Council at that time $(2007 / 60 / \mathrm{ES}$ of October 23, 2007) on the assessment and management of flood risks. Our project offers an alternative approach to the problems of flood protection, leading not only to a better status for the landscape and the migration permissiveness of water courses, but also to important saving of costs. This approach also enables larger numbers of flood analyses to be processed, and consequently leads to secondary application of the results to the protection of citizens' lives and property, crisis management, or complex land adaptation design.

The main measures considered in the catchment area should reduce water erosion and eliminate the nutrient load of water, increase water retention in the landscape and at the same time preserve the productive capacity of the soil. These measures are associated with the implementation of adequate agricultural practices. The measures in the landscape should not be underestimated because they represent an important part of the preventive measures.

In terms of the economic effectiveness of the proposed measures, a large number of flood-control measures should be implemented, with significant consequences for the crisis management, as well as their incorporation into the flood-control plans of settlements, larger villages and regions, thus eliminating the impact of flood events on human health, the environment, cultural heritage and agricultural activities.

Another highly positive effect is the use of the territory for developing the quality of surface and underground water. The fact that the territory exploitation and especially grassing positively influences water quality has been demonstrated in many research reports: see, for example, Klimeš and 


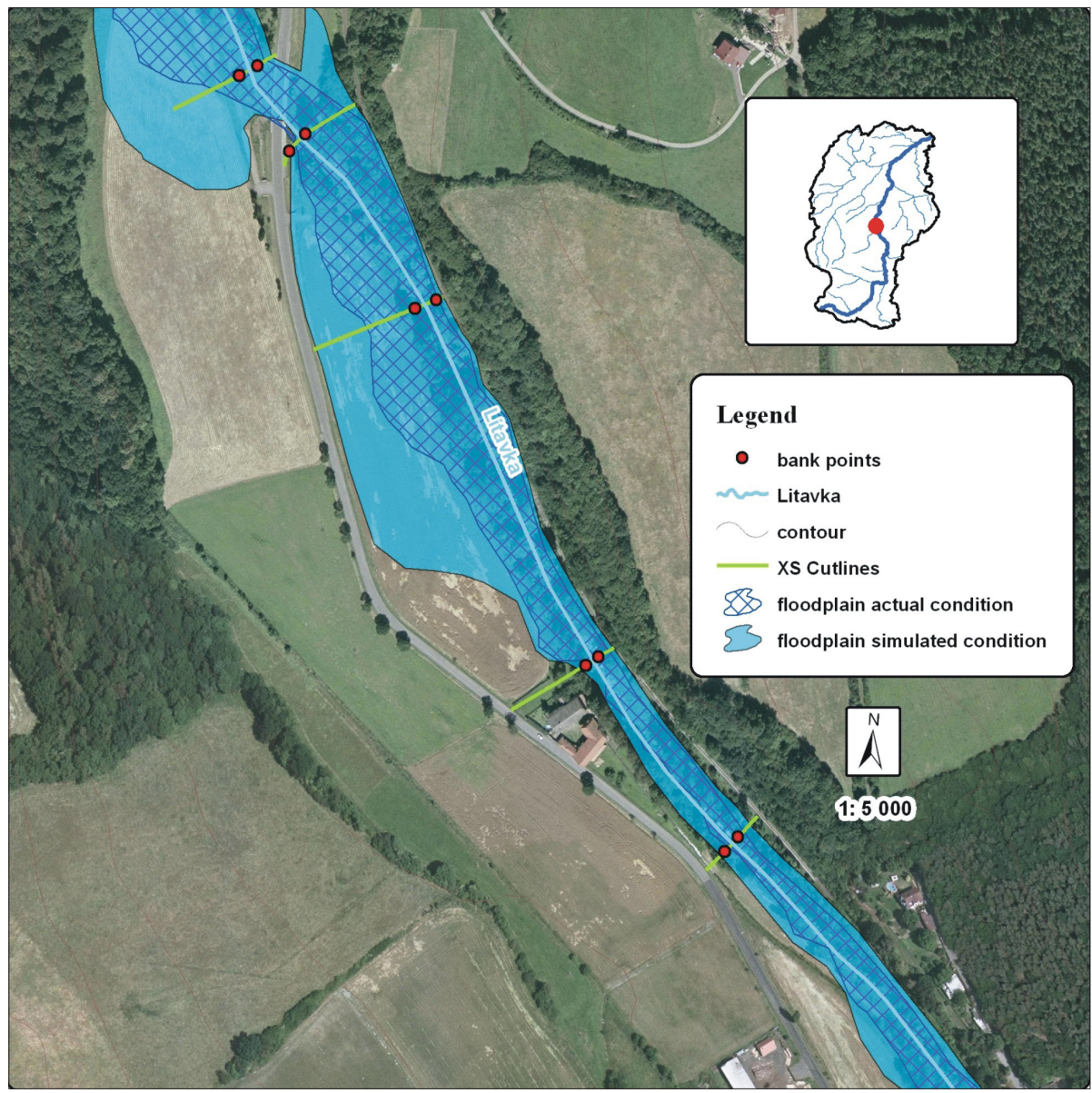

Fig. 9: Floodplain

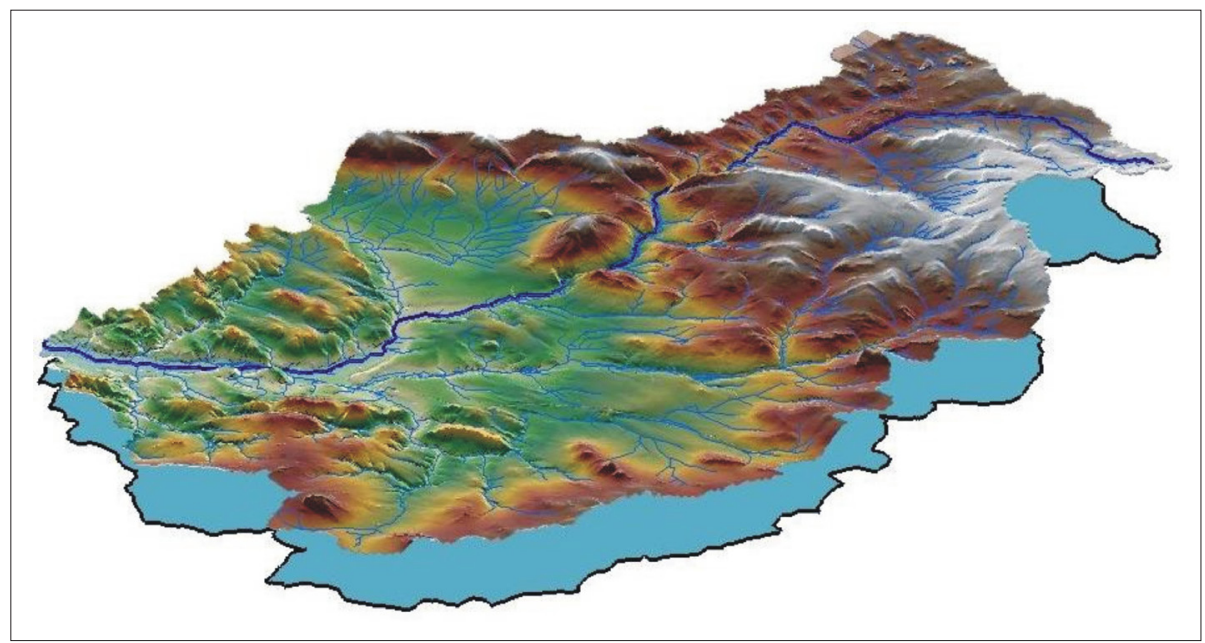

Fig. 10: Morphology of the catchment

Kužel (2004), Klimeš et al. (2004), Kvítek (2002), Poor and McDonnell (2007), and Stanley et al. (2003).

Although we cannot generalize these partial results, we can conclude that our proposed AFM will improve conditions of life for water organisms, the self-cleaning capacity of the water course, and namely increase flood protection both at the water course and in the alluvial plain.

\section{Acknowledgement}

This contribution was supported by the Research Programmes of the Ministry of Agriculture of the Czech Republic No. MZE 0002704902, by the Project No. TA02020139 of the Technology Agency of the Czech Republic and with the support by the Project No. QH QI91C200 of the National Agency for Agricultural Research of the Czech Republic. 


\section{References:}

ADAMEC, M., BŘEZKOVÁ, L., HANZLOVÁ, M., HORÁK, J., UNUCKA, J. (2006): Modelování vlivu land use na srážkoodtokové vztahy s podporou GIS. Příspěvek na konferenci Řiční krajina 4. Olomouc, PřF UPOL, p. 335-350.

ADAMEC, M., UNUCKA, J. (2007): Modelování vlivu land use na erozní procesy s podporou GIS. In: sborník konference Říční krajina 2007. PřF UP, Olomouc, 10 pp.

ANDERSON, D. J. (2000): GIS-based hydrologic and hydraulic modeling for floodplain delineation at highway river crossings. MS, University of Texas at Austin, URL: http://www.crwr.utexas.edu/online.shtml.

ANDRYSIAK, P. B., MAIDMENT, D. (2000): Visual Floodplain Modeling with Geographic Information Systems (GIS). MS, University of Texas at Austin. Available at: URL: http://www.crwr.utexas.edu/online.html.

BIČÍK, I., LANGHAMMER, J., ŠTYCH, P., KUPKOVÁ, L. (2008): Long-term land-use changes in Czechia as a flood risk influencing factor. Acta Universitatis Carolinae, Geographica, Vol. 45, No. 1-2, p. 29-52.

BOONSTRA, J., RITZEMA, H. P. [editor-in-chief] (1994): Drainage Principles and Applications. ILRI Publication 16. ILRI, P.O.Box 45, 6700AA Wageningen, The Netherlands.

BRÁZDIL, K. (2009): Projekt tvorby nového výškopisu území České republiky. Geodetický a kartografický obzor, Vol. 55 (97), No. 7, p. $145-151$.

COLBY, J. D., MULCAHY, K. A., WANG, Y. (2000): Modeling flooding extent from Hurricane Floyd in the coastal plains of North Carolina. Environmental Hazards, Vol. 2, p. 157-168.

DOLANSKÝ, T. (2004): Lidary a letecké laserové skenování. Acta Universitatis Purkynianae, Vol. 99, Studia geoinformatica, Univerzita J. E. Purkyně v Ústí nad Labem, 100 pp.

DRBAL, K. et al. (2009): Metodika tvorby map povodňového nebezpečí a povodňových rizik. Ministerstvo životního prostředí, $84 \mathrm{pp}$.

FELDMAN, A. D. (2000): Hydrologic Modeling System HEC-HMS, Technical Reference Manual. USACE, Davis, 155 pp.

FOWLER, H. J., EKSTRÖM, M., KILSBY, C. G., JONES, P. D. (2005): New estimates of future changes in extreme rainfall across the UK using regional climate model integrations. Assessment of control climate. Journal of Hydrology No. 300, p. 212-233.

GIANNONI, F., SMITH, J. A., ZHANG, Y., ROTH, G. (2003): Hydrologic modeling of extreme floods using radar rainfall estimates. Advances in Water Resources, Vol. 26, No. 2, p. 195-203.

HALL, D. G. M, REEVE, M. J, THOMASSON, A. J, WRIGHT, V.F. (1977): Water retention porosity and density of field soils. Soil Survey Technical Monograph No. 9: Soil Survey of England and Wales. (Lawes Agricultural Trust: Harpenden), 75 pp.

HAVLÍK, A., SALAJ, M., SATRAPA, L., FOŠUMPAUR, P., HORSKÝ, M. (2004): Metodika mapování povodňových rizik s pomocí geografických informačních systémů. Praha, ČVUT, Fakulta stavební, 34 pp.

HAVLOVÁ, J. (2001): Ekologická studie Litavky. Hydroprojekt. Praha, 332 pp.

HOLÝ, M. (1994): Eroze a životní prostředí, Vydavatelství ČVUT Praha, 383 pp.

HORNBECK, J. W., BAILEY, S. W., BUSO, D. C., SHANLEY, J. B. (1997): Streamwater Chemistry and Nutrient Budgets for Forested Watersheds in New England: Variability and Management Implications. Forest Ecology and Management, No. 93, p. 73-89.

HRABĚ, F., BUCHGRABER, K. (2004): Pícninářství, Travní porosty, Brno, MZLU (Skriptum), 151 pp.

CHLEBEK, A., JAŘABÁČ, M. (1988): Důsledky porostních obnov na odtok vody z beskydských experimentálních povodí, Zprávy lesnického výzkumu, No. 4, p. 7-12.

CHOW, V. T., MAIDMENT, D. R., MAYS, L. W. (1998): Applied hydrology, McGraw-Hill, New York, 570 pp.

JANEČEK, M. et al. (1992): Ochrana zemědělské půdy před erozí: Metodika UVTIZ No. 5, 110 pp.

JANEČEK, M. et al. (2002): Ochrana zemědělské půdy před erozí. 1. vyd. Praha, ISV, 201 pp.

JENÍČEK, M. (2008): Přehled srážko-odtokových modelů, studijní materiál pro potřeby posluchačů předmětu „Modelování hydrologických procesü“, Univerzita Karlova v Praze.

JENÍČEK, M. (2009): Runoff changes in areas differing in land-use in the Blanice River basin - application of the deterministic model. Journal of Hydrology and Hydromechanics, Vol. 57, No. 3, p. 154-161.

KAIML, P. (2000): Kvalita povrchových vod v povodí Litavky. Diplomová práce. KFGG PřF UK, Praha, 142 pp.

KANTOR, P., KREČMER, V., ŠACH, F., ŠVIHLA, V., ČERNOHOUS, V. (2003): Lesy a povodně: Souhrnná studie; Praha, Národní lesnický komitét a Ministerstvo životního prostředí, p. 48. 
KLEMENTOVÁ, E., JURÁKOVÁ, M. (2003): Mokradě v systéme protipovodňovej ochrany. Životné prostredie, Vol. 37, No. 4. Available at: URL: http://www. seps.sk/zp/casopisy/zp/2003/zp4/index.htm.

KLIMEŠ, F. et al. (2004): A possibility to control of ground water contamination with nitrates by suitable grassland management. Coll. of Sci. Papers, Faculty of agriculturae in České Budějovice, Series of Crop Science, Vol. 21, No. 1, p. 41-43.

KLIMEŠ, F., KUŽEL, S. (2004): Application of modelling by the study of ground water contamination with nitrates under grasslands. Plant Soil and Envir., Vol. 50, No. 3, p. 122-128.

KOSUGI, K., MORI, K., YASUDA, H. (2001): An inverse modeling approach for the characterization of unsaturated water flow in an organic forest floor. In: Journal of Hydrology, No. 246, p. 96-108.

KŘOVÁK, F., PÁNKOVÁ, E., DOLEŽAL, F. (2004): Vliv lesních ekosystémů na hydrický režim krajiny. In: Aktuality šumavského výzkumu II, Srní 4.-7. října 2004, p. 44-48.

KVÍTEK, T. et al. (2002): Diferencovaný způsob obhospodařování travních porostů ve vztahu k jakosti vody a stanovištním podmínkám. Sborník z mezinárodní konference „Obhospodařování travních porostů a jejich využití skotem v době přibližování Č́R do evropské unie“, VÚRV Praha, 20.3.2002, p. 113-220.

LANGHAMMER, J. (2007): Upravenost toků a údolní nivy jako faktor ovlivňující průběh a následky povodní, In: Langhammer, J. [ed]: Sborník Změny v krajině a povodňové riziko, p. 129-142.

LIKENS, G. E., BORMANN, F. H. (1974): Effects of Forest Clearing on the Northern Hardwood Forest Ecosystom and its Biochemistry. Proceedings of the First International Congres of Ecology, 8-14.9. 1974; The Hague; The Netherlands. Wageningen: Centre for Agricultural Publishing and Documentation, p. 330-335.

MAHE, G. E., SERVAT (2005): The impact of land use change on soil water holding capacity and river flow modelling in the Nakambe River, Burkina-Faso. Journal of Hydrology, Vol. 300, p. 33-43.

MAIDMENT, D. R. (2002): ArcHydro - GIS for Water Resources. Publisher: ESRI Press, DVD-ROM, 220 p.

MAGUNDA, M. K., LARSON, W. E., LINDEN, D. R., Nater, E. A. (1997): Changes in microrelief and their effects on infiltration and erosion during simulated rainfall. Soil Technology, Vol. 10, No. 1, p. 57-67.

MAUCHAMP, A., CHAUVELON, P., GRILLAS, P. (2002): Restoration of floodplain wetlands: Opening polders along a coastal river in Mediterranean France, Vistre marshes. Ecological Engineering, p. 619-632.

MERWADE, V. M., COOK, A., COONROD, J. (2008): GIS techniques for creating river terrain models for hydrodynamic modeling and flood inundation mapping, Environmental Modelling \& Software, Vol. 23, p. 1300-1311.

MERWADE, V. M., MAIDMEND. R., GOFF, J.A. (2006): Anisotropic considerations while interpolating river channel bathymetry. Journal of Hydrology, No. 331, p. 731-41.

MISHRA, S. K., SINGH, V. P. (2003): Soil Conservation Service Curve Numer (SCS-CN) Methodology. Dordrecht, Kluwer Academic Publisher, 511 pp.

MUNZAR, J., ONDRÁČEK, S., ELLEDER, L., SAWICKI, K. (2008): Disastrous floods in Central Europe at the end of July 1897 and the lessons learnt. Moravian Geographical Reports, Vol. 16, No. 3, p. 13-26.

NOVÁK P., ROUB, R., HEJDUK T. (2011): Využití hydrologického měření při tvorbě hydrodynamických modelů z dat leteckého laserového skenování. Vodní hospodářství, Vol. 61, No. 8, p. 297-302.

NOVÁK, P. et al. (2003): Zpracování digitálních map hydropedologických charakteristik půd České republiky. Závěrečná zpráva a výstup 02 projektu QD 1368 „Verifikace metod odvození hydrologických podkladů pro posuzování bezpečnosti vodních děl za povodní“, VÚMOP, Praha, 11 pp.

O’CONNOR, K. M. (1976): A discrete linear cascade model for hydrology. Journal of Hydrology, Vol. 29, p. $203-242$.

PETŘÍČEK, V., CUDLÍN, P. (2003): Máme bojovat proti povodním? Životné prostredie, Vol. 37, No. 4, p. 177-179. Available at: URL: http://www.seps.sk/zp/casopisy/ zp/2003/zp4/index.htm.

POBĚDINSKIJ, A. V., KREČMER, V. (1984): Funkce lesů v ochraně vod a půdy, 1. vyd. Praha, Státní zemědělské nakladatelství, $256 \mathrm{pp}$.

PODRÁZSKÝ, V., REMEŠ, J. (2006): Retenční schopnost lesních ekosystémů. Lesnická práce, Vol. 85, No. 7, p. 232, URL: http://lesprace.silvarium.cz.

PONCE, V. M., HAWKINS, R. H. (1996): Runoff Curve Number: Has it Reached Maturity, Journal of Hydrologic Engineering, Vol. 1, No. 1, ASCE, USA (p. 11-19).

POOR, C. J., MCDONNELL, J. J. (2007): The effect of land use on stream nitrate dynamics. Jurnal of Hydrology, No. 332, p. $54-68$.

QUITT, E. (1971): Klimatické oblasti Československa. Studia Geographica 16, Brno, Academia, Geografický ústav ČSAV, 73 pp. 
RAPANT, P. (2002): Úvod do geografických informačních systémů. Vysoká škola báňská - Technická univerzita Ostrava, Hornicko-geologická fakulta, Institut ekonomiky a systémů řízení, oddělení GIS, Ostrava, 110 pp.

RAPANT, P. (2005): Geoinformační technologie. Vysoká škola báňská - Technická univerzita Ostrava, Hornicko-geologická fakulta, Institut geoinformatiky, Ostrava, $125 \mathrm{pp}$.

ROUB, R., HEJDUK, T., NOVÁK, P. (2012): Využití dat z tvorby nového výškopisu území České republiky metodou leteckého laserového skenování při analýze a mapování povodňových rizik. Geodetický a kartografický obzor, Vol. 58/100, No. 1, p. 4-8.

SHALABY, A., TATEISHI, R. (2007): Remote sensing and GIS for mapping and monitoring land cover and land-use changes in the Northwestern coastal zone of Egypt. Applied Geography, Vol. 27, No. 1, p. 28-41.

SKALOŠ, J.,WEBER, M., LIPSKÝ, Z., ŘEPÁKOVÁ, I., ŠANTRU゚ČKOVÁ, M., UHLÍŘOVÁ, L., KUKLA, P. (2011): Using old military survey maps and orthophotograph maps to analyse long-term land cover changes: case study (Czech Republic). Applied Geography, No. 31, p. 426-438.

SMĚRNICE EVROPSKÉHO PARLAMENTU A RADY 2007/60/ES ze dne 23. října 2007 o vyhodnocování a zvládání povodňových rizik (povodňová směrnice).

STANLEY, C. D., CLARKE, R. A., McNEAL, B. L., MACLEOD, B. W. (2003): Impact of Agricultural Land Use on Nitrate Levels in Lake Manatee, Florida. Soil and Water Science Department, Florida Cooperative Extension Service, IFAS, University of Florida, 9 pp.

TAUFMANNOVÁ, A., LANGHAMMER, J. (2007): Mapování antropogenní upravenosti toků a následků povodní v povodí Horní Litavky. In: Langhammer, J. [ed.]: Změny v krajině a povodňové riziko, p. 213-220.

TESAŘ, M., ŠÍR, M., DVOŘÁK, I. J. (2003): Vliv vegetačního porostu a jeho změn na vodní režim půd v pramenných oblastech Krkonoš. In: Sborník mezinárodní vědecké konference „Geologické problémy Krkonoš“. Szklarska Poręba, listopad 2003, p. 30-37.

TRIMBLE, S. W. (2003): Historical hydrographic and hydrologic changes in the San Diego creek wathershed, Newport Bay, California. Journal of Historical Geography, Vol. 29, No. 3, p. 422-444.

TRIZNA, M. (2002): Runoff modelling and its spatial variability in dependence on land use. Moravian Geographical Reports, Vol. 15 , No. 3, p. 41-58.

TRIZNA, M., KYZEK, F. (2002): Modelovanie špecifických zrážkovo-odtokových situácií vo vybranom povodí. In: Balej, M., Jančák, V., Jeřábek, M., Oršulák, T. [eds.]: Česká společnost a krajina, Sborník s XX. Sjezdu České geografické společnosti, Ústí nad Labem, p. 56-72.

UHLÍŘOVÁ, K., ZBOŘIL, A. (2009): Možnosti využití Laserového snímání povrchu pro vodohospodářské účely. Vodní hospodářství, Vol. 59, No. 12, p. 11-15.

UNUCKA, J., ADAMEC, M. (2008): Modelování vlivu krajinného pokryvu na srážkoodtokové vztahy v povodí Olše. Journal of Hydrol. Hydromech., Vol. 56, No. 4, p. 257-271.

UNUCKA, J. (2008): Modelování vlivu lesa na srážkoodtokové vztahy a vodní erozi s pomocí GIS. Vodní hospodářství, Vol. 58, No. 7, p. 225-231.

VOPÁLKA, J. (2003): Přístup ministerstva životního prostředí k problematice povodní. In: Celostátní seminář Lesy a povodně. Praha, ČLS, MŽP, MZe, 25.6.2003, p. 8-11.

VOŽENÍLEK, V. (2000): Geografické informační systémy I: Pojetí, historie, základní komponenty. Olomouc, Přírodovědecká fakulta Univerzity Palackého, 174 pp.

WEYSKRABOVÁ, L., VALENTOVÁ, J., VALENTA, P., MYSLIVEC, D., FOŠUMPAUR, P., ŠEPELÁK, J. (2010): Hydraulické a hydrologické přístupy ke stanovení retenční kapacity říční nivy. In: sborník konference Voda a krajina. Praha, Katedra hydromeliorací a krajinného inženýrství, ČVUT v Praze, Fakulta stavební, p. 134-141.

Zákon č. 254/2001 Sb. o vodách a o změně některých zákonů (vodní zákon).

ŽIKULINAS, J. (2008): Hydrographic changes of the Streva Basin in the $20^{\text {th }}$ century. Part 1 . Water streams. Geografija, Vol. 44, No. 1, p. 26-30.

\section{Authors' addresses:}

Ing. Radek ROUB, Ph.D., e-mail: roub@fzp.czu.cz

Czech University of Life Sciences Prague, Faculty of Environmental Sciences

Department of Water Resources and Environmental Modeling

Kamýcká 129, 16521 Praha 6-Suchdol, Czech Republic 
RNDr. Pavel NOVÁK, e-mail: novak.pavel@vumop.cz

Research Institute for Soil and Water Conservation

Žabovřeská 250, 15627 Prague 5-Zbraslav, Czech Republic

Ing. Tomáš HEJDUK, e-mail: hejduk.tomas@vumop.cz

Research Institute for Soil and Water Conservation

Žabovřeská 250, 15627 Prague 5-Zbraslav, Czech Republic

Initial submission 30 June 2012, final acceptance 10 March 2013

Please cite his article as:

ROUB, R., HEJDUK, T., NOVÁK, P. (2013): Optimization of Flood Protection by Semi-natural Means and Retention in the Catchment Area: A Case Study of Litavka River (Czech Republic). Moravian Geographical Reports, Vol. 21, No. 1, p. 51-66. 